\title{
FIRST REPORT OF THELAZIA CALIFORNIENSIS PRICE (NEMATODA, THELAZIOIDEA) IN SOUTH AMERICA FROM THE EYES OF A BRAZILIAN DEER, MAZAMA GOUAZOUPIRA (FISCHER) (MAMMALIA, CERVIDAE)
}

\author{
Roberto Magalhães Pinto 1, 2, 3 \\ Joaquim Júlio Vicente ${ }^{1,2}$ \\ Henrique de Oliveira Rodrigues ${ }^{1}$
}

\begin{abstract}
Data on Thelazia californiensis Price, 1930 are presented. The importance of this eye nematode is also related to a few human cases due to this parasite in the USA. This is the first report of $T$. californiensis occurring in a South American host, Mazama gouazoupira (Fischer, 1814), which is also a new record for the species. KEY WORDS. Nematode, Thelazia californiensis, mammal, deer, Brazil
\end{abstract}

The finding of a single male worm of Thelazia californiensis Price, 1930 in the eyes of a Brazilian mammal, justifies the present notification, taking into account that many species remain unreported, if they are overlooked during necropsies scheduled to attend quantitative recoveries.

Thus, the report of $T$. californiensis also referred in cases of human thelaziiasis and occurring for the first time in a South American host is presented.

The nematode sample was collected from the eyes of the single specimen of Mazama gouazoupira (Fischer, 1814) necropsied in Tapajós, State of Pará, in the middle of the 1940s and was fixed in a 10\% formaldehyde solution. Processing of the helminth for study, photomicrography and illustrations were obtained as described elsewhere (PINTO et al. 1993; PINTO \& VICENTE 1995). Measurements are in micrometers unless otherwise indicated. NHR and NGR refer to New Host Record and New Geographical Record, respectively.

Thelazioidea, Thelaziidae, Thelaziinae

\section{Thelazia californiensis Price, 1930}

Figs 1-4

Morphometrics. Body $7.65 \mathrm{~mm}$ long, 250 wide. Oral aperture simple, surrounded by six small and inconspicuous papillae. Buccal capsule 14 long, 21 wide. Esophagus 380 long. Nerve ring 230 from anterior extremity. Left spicule long, slender, wrinkled in the fixed specimen, $2.01 \mathrm{~mm}$ long. Right spicule stout,

1) Laboratório de Helmintos Parasitos de Vertebrados, Departamento de Helmintologia, Instituto Oswaldo Cruz. Avenida Brasil 4365, 21045-900 Rio de Janeiro, Rio de Janeiro, Brasil.

2) CNPq research fellow.

3) Corresponding author. E-mail: rmpinto@gene.dbbm.fiocruz.br 


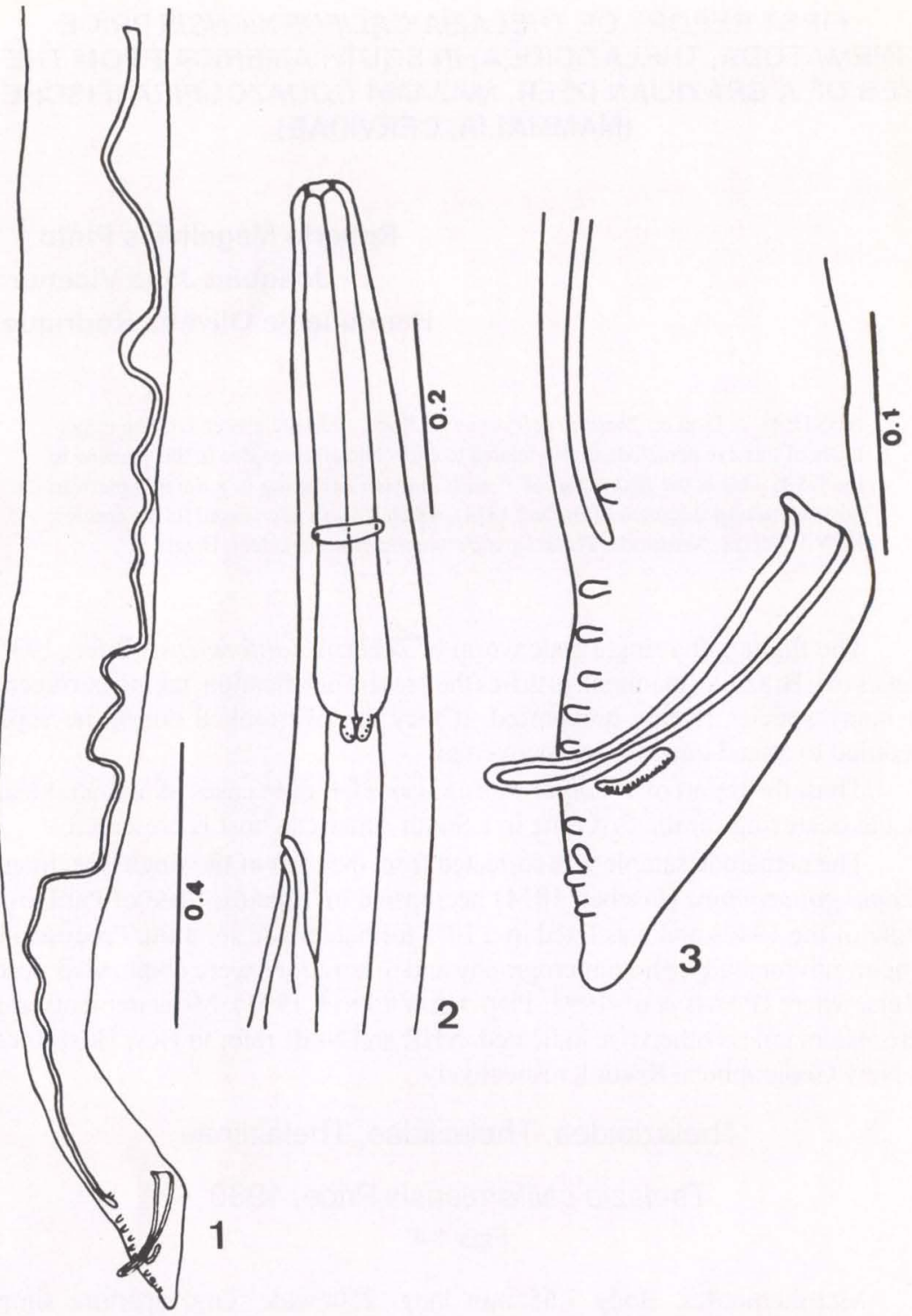

Figs 1-3. Thelazia californiensis. (1) Posterior portion of male, lateral view; (2) anterior portion of male, lateral view; (3) posterior extremity of male, lateral view. Bars in millimeters.

160 long. Gubernaculum 25 long with a spongy aspect, easily overlooked (Fig. 4). Ten pairs of pedunculate caudal papillae. Caudal alae absent. Cloacal aperture, 90 from posterior extremity.

Host: Mazama gouazoupira (Fischer, 1814) - NHR

Site of infection: surface of the eyeball 


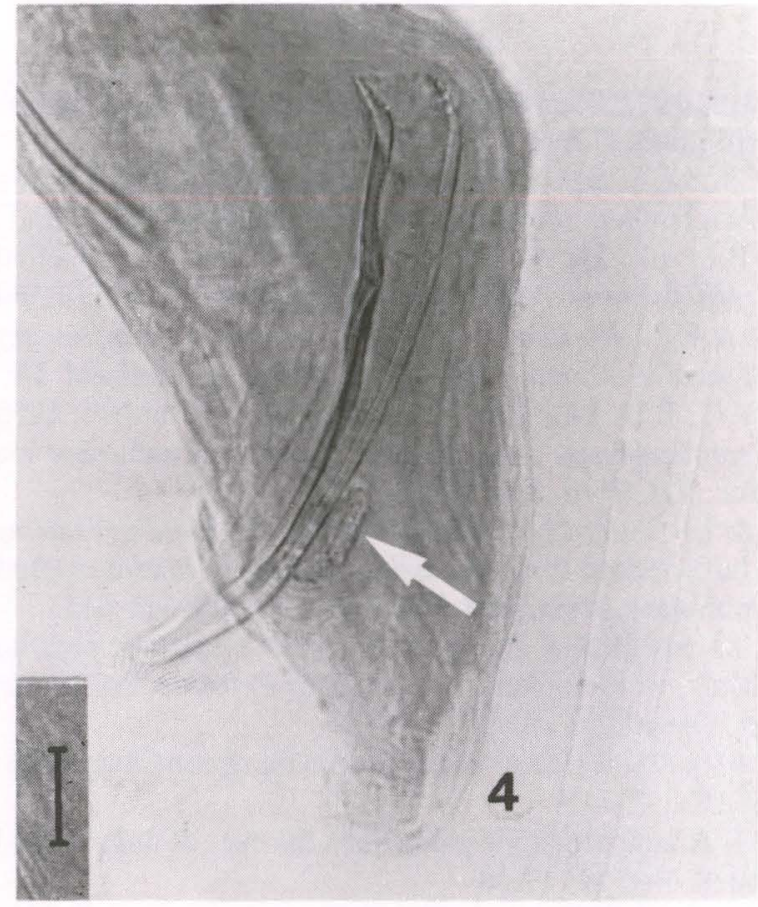

Fig. 4. Thelazia californiensis. (4) Posterior extremity of male, lateral view. Gubernaculum is indicated by the arrow. Bar $=0.03 \mathrm{~mm}$.

Locality: Tapajós, State of Pará, Brazil - NGR

Other localities: several counties in California, USA.

Specimen deposited: Helminthological Collection of the Oswaldo Cruz Institute no. 33,736 (whole mount).

Thelazia californiensis was proposed by PRICE (1930) on basis on specimens recovered from the eyes of dogs in the USA. Although the full description of the species only appeared later (PRICE 1931), the valid year is undoubtedly 1930, in spite of some authors refer erroneously to 1931 (HosFORD et al. 1942).

Thelazia californiensis has been reported parasitizing the exterior region of the eyes of dogs, deers and less commonly the eyes of several mammals, including man (PARMELEE et al. 1956). The third-stage infective larvae occurring in muscid flies, migrate to the head of the fly, which they leave when the latter feeds about the eyes of the definitive host. Female worms produce large numbers of eggs, which embryonate "in utero" into active fully differentiated first-stage larvae which are deposited into the lacrimal secretions of the host, to be ingested by the flies during the feeding process (ANDERSON 1992).

The infection of $T$. californiensis in man generally produces rather mild symptoms, related to conjunctivitis and excessive lacrimation (KOFOID \& WILLIAMS 1935; HOSFORD et al. 1942; KIRSCHNER et. al. 1990). 


\section{REFERENCES}

ANDERSON, R.C. 1992. Nematode parasites of vertebrates. Their development and transmission. C.A.B. International, XIII $+578 \mathrm{p}$.

Hosford, G.N.; M.A. STEWART \& E.I. Sugarman. 1942. Eye worm (Thelazia californiensis) infection in man. Arch. Ophthalmol. 27: 1165-1170.

KIRSCHNER, B.I.; J.P. DUNN \& H.B. OSTLER. 1990. Conjunctivitis caused by Thelazia californiensis. Amer. Jour. Ophthalmol. 110: 573-574.

KoFoID, C.A. \& O.L. WiLliams. 1935. The nematode Thelazia californiensis as a parasite of the eye of man in California. Arch. Ophthalmol. 13: 176-180.

PARMELEE, W.E.; R.D. LeE; E.D. WAGNER \& H.S. BuRnetT. 1956. A survey of Thelazia californiensis, a mammalian eye worm, with new locality records. Jour. Amer. Vet. Med. Ass. 129: 325-327.

PINTO, R.M. \& J.J. VICENTE. 1995. Tetrameres (Tetrameres) spirospiculum n. sp. from the buff-necked ibis, Theristicus caudatus caudatus (Boddaert) (Aves, Threskiornithidae). Mem. Inst. Oswaldo Cruz 90: 615-617.

PINTO, R.M.; J.J. VICENTE \& D. NORONHA. 1993. Nematode parasites of Brazilian psittacid birds, with emphasis on the genus Pelecitus Railliet \& Henry, 1910. Mem. Inst. Oswaldo Cruz 80: 279-284.

PRICE, E.W. 1930. A new nematode parasitic in the eyes of dogs in the United States. Jour. Par. 17: 112-113. 1931. A new nematode parasitic in the eyes of dogs in the United States.

North. Amer. Vet. 12: 49-58.

Recebido em 29.VIII.1997; aceito em 04.XII.1998. 